Romanticism on the Net

An open access journal devoted to British Romantic literature

Ro Romanticism on the Net

\title{
Introduction-Southeyan Correspondences
}

\section{Tim Fulford et Matthew Sangster}

Numéro 68-69, spring-fall 2017

Robert Southey

URI : https://id.erudit.org/iderudit/1070618ar

DOI : https://doi.org/10.7202/1070618ar

Aller au sommaire du numéro

Éditeur(s)

Université de Montréal

ISSN

2563-2582 (numérique)

Découvrir la revue

Citer ce document

Fulford, T. \& Sangster, M. (2017). Introduction-Southeyan Correspondences.

Romanticism on the Net, (68-69). https://doi.org/10.7202/1070618ar d'utilisation que vous pouvez consulter en ligne. 


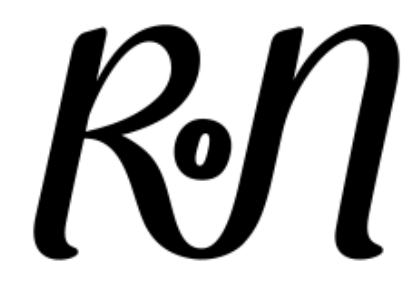

\section{Romanticism on the Net}

\section{Introduction-Southeyan Correspondences}

Tim Fulford and Matthew Sangster

De Montfort University and University of Glasgow

\section{Biographical Note}

Tim Fulford is Professor of English at De Montfort University. He writes on Romantic era literature in the contexts of colonialism, exploration, science, landscape, the picturesque, and religion. He has published many articles and books on these topics, featuring such writers as William Wordsworth, S. T. Coleridge, Robert Bloomfield, Mary Robinson, William Cowper, Jane Austen, and John Clare. He is currently preparing scholarly editions of the writings of Robert Bloomfield and the letters of Humphry Davy. His next monograph will be a study of Wordsworth's poetry from 1815 to 1845.

Matthew Sangster is a Lecturer in Eighteenth-Century Literature and Material Culture at the University of Glasgow. He has published widely on Romantic-period subjects and on genre. He is particularly interested in authorship, material culture, library history, reading audiences, institutional practices, the 1820s, representations of London, and the digital humanities. He is currently completing a monograph entitled Living as an Author in the Romantic Period. His most recent publication is an essay on Southey's vexed relationship with London in this special issue. 


\section{Romanticism on the Net \#68-69 (Spring-Fall 2017). Special issue on Robert Southey. Guest-edited by Tim Fulford (De Montfort University) and Matthew Sangster (University of Glasgow)}

1. Accounts of Robert Southey that consider his achievements over the longer term often arc towards the tragic. In her 2015 exploration of the mechanics of lasting literary fame, Those Who Write for Immortality, H. J. Jackson describes him as "a byword for posthumous failure that seems all the more pathetic - or ironic, or ludicrous - in light of his aggressive pursuit of success" (51). For Jackson, and for other critics, such as Michael Gamer, who in 2017 provided a compelling and engaging account of Southey's "lifelong struggle to maintain a coherent authorial identity" (195), Southey spent his considerable energies in ways that proved largely to be futile when it came to the construction of an enduring position within the literary canon. However, as both Gamer and Jackson show, Southey's complicated relationship with conventional ideals of canonicity is one of the many things that make him a fascinating figure for twenty-first-century readers and scholars. His polymathic and multiform productivity sits uncomfortably within the more restricted models of literary art that achieved dominance over the course of the nineteenth century, as Romantic paradigms derived in large part from his Lake School contemporaries, William Wordsworth and Samuel Taylor Coleridge, reshaped the cultural position of writing. However, these Romanticising paradigms are far from the only means by which we can value literary works and careers, and over the past forty years they have rightly been subjected to increasing critical scrutiny. As Jerome J. McGann's The Romantic Ideology (1983) and Clifford Siskin's The Historicity of Romantic Discourse (1988) have demonstrated, the retrospective construction of "Romanticism" produced historically situated standards, rather than eternal verities. Southey provides potent means for questioning these standards, offering opportunities for recovering discourses that the posthumous editorial force of Romanticisation has occluded and for studying models of creativity and influence that trace revealing alternatives to those propagated by his more canonical contemporaries.

2. Southey himself was confident that an interest in his life and works would endure. As he put it when writing to his friend Charles Watkin Williams Wynn about the value of his memoirs in April 1812, "there can be no doubt that I shall be sufficiently talked of whenever I am gone" (CLRS 2078). However, had he been granted the ability to view his twentieth-century reception, he might have thought that for much of that period the critical conversation regarding his works was not a sufficient one. John Mullan writes that when in 1986 Marilyn Butler "devoted her inaugural lecture on appointment to the Edward VII chair of English in Cambridge to the poetry of Robert Southey ... [s]ome of her new colleagues were evidently perplexed by her interest in 


\section{Romanticism on the Net \#68-69 (Spring-Fall 2017). Special issue on Robert Southey. Guest-edited by Tim Fulford (De Montfort University) and Matthew Sangster (University of Glasgow)}

such a subsidiary writer." However, the following decades have seen an enormous upsurge in attention. While between 1980 and 1989 Southey appeared only forty-one times in publications indexed in the MLA International Bibliography, between 1990 and 1999 he appeared seventysix times and between 2000 and 2009 he featured 123 times: an exact tripling relative to the 1980s. Once the articles in this special issue and other Southey-related works published during 2018 are indexed, it seems likely that twenty-first-century scholarly publications in which Southey is a noteworthy presence (255 at the time of writing) will overtake in quantity those dating from between 1910 and 1999 (278).

3. In the introduction to her edited collection Robert Southey and the Contexts of English Romanticism (2006), Lynda Pratt credits-along with Butler-Nigel Leask's British Romantic Writers and the East (1992), Mark Storey's Robert Southey: A Life (1997), and Tim Fulford and Peter Kitson's Romanticism and Colonialism (1998) with engendering a situation where "Southey has at last started to become a writer worth reading" (xix). Pratt's collection was the culmination of the first phase of a new Southey scholarship that was also instantiated in a special issue of Romanticism on the Net that she edited in 2003, with contributions from Ian Haywood, David Chandler, Simon Bainbridge, Tim Fulford, Carol Bolton, Esther Wohlgemut, Catherine Addison, and Herbert Tucker. This wave of Southey studies was constituted principally around situating Southey biographically, considering his imperial entanglements, and mapping his poetic interactions with canonical genres and figures. Major strands within Pratt's 2006 collection examine Southey's engagements with literary history, his political writings, and the global reach of his earlier poems, particularly their treatments of America and the Orient. The 2003 special issue traced Southey's relationships with poets including Wordsworth, Coleridge, and Byron; revisited his republicanism; and paid considerable attention to his major epics.

4. The scholarly achievements of this period paved the way for a significant revival of interest in Southey, but the ability of critics to further engage with him in the early 2000s was hampered by the limited availability of his writings. In her 2006 introduction, Pratt wrote, "Our own sense of his works is a fragmented one, the result of decades of neglect and of the current lack of scholarship on establishing a canon of his complete works" (xxi). In prefacing a 2011 special issue of Romanticism, she reinforced her sense of the difficulty of encompassing Southey's 


\section{Romanticism on the Net \#68-69 (Spring-Fall 2017). Special issue on Robert Southey. Guest-edited by Tim Fulford (De Montfort University) and Matthew Sangster (University of Glasgow)}

range, describing his oeuvre as "vast, disparate and transnational" (2011, v). The 2004 publication of Poetical Works 1793-1810 was a crucial first step in providing fully contextualised versions of Southey's writings, complete with modern editorial apparatus and interpretive frameworks. However, in the last few years, this landmark has been joined by a further series of pathbreaking critical editions, including the Collected Letters of Robert Southey (the first instalment of which was published in 2009), the Later Poetical Works, 1811-1838 (2012), the Letters from England by Don Manuel Alvarez Espriella (2016), and Sir Thomas More: or, Colloquies on the Progress and Prospects of Society (2017). Alongside these works can be placed W. A. Speck's important biography, Robert Southey: Entire Man of Letters (2006), and the research undertaken by Jonathan Cutmore and others that lets us trace Southey's periodical writings for the Quarterly Review (2005). These editions have provided opportunities for a new wave of Southey scholarship that ranges more extensively across his complex oeuvre. The one hundred and fifty-eight entries in the MLA bibliography with which Southey's name has been associated in the past ten years show that he has featured regularly in a wide variety of essay collections and journal issues while also playing a starring or a prominent supporting role in a considerable number of recent monographs, including books by Stuart Andrews, Carol Bolton, Ashley Cross, David M. Craig, Tim Fulford, Humberto Garcia, Jen Hill, Andrew Rudd, Adrian J. Wallbank, Andrew Warren, and Alex Watson.

5. It is in the context of this flourishing scene that the current special issue emerges. The essays included here were worked up from papers presented at the fourth international Robert Southey conference, held in Bristol in April 2017. These articles are all beneficiaries of the recent wave of new editions and serve to demonstrate the diverse range of historical and critical possibilities that Southey opens up now that a more holistic impression of his activities can be gleaned. Collectively, the contributors flesh out our understanding of Southey's engagements with scientific progress, ecology and the environment, Hispanic literary and cultural traditions, Romantic-era systems of knowledge, the intricacies of political interactions, nations and national identities, industrialisation and technology, urbanisation, and localities. In engaging with Southey's preoccupations, the contributors also demonstrate a range of ways in which his works can be used to challenge our preconceptions about Romantic writing and Romanticperiod cultural history through providing correctives, complications, and alternatives. 


\section{Romanticism on the Net \#68-69 (Spring-Fall 2017). Special issue on Robert Southey. Guest-edited by Tim Fulford (De Montfort University) and Matthew Sangster (University of Glasgow)}

6. The first article, Ian Packer's detailed account of Southey's political interactions in 1816 and 1817, clearly displays the value of the new collected correspondence for understanding the wider implications of Southey's public pronouncements. Reading the Wat Tyler controversy through the lens of Southey's larger political programme - as expressed informally in letters to his friends and more formally in letters to leading government figures-Packer demonstrates the extent of and limits upon Southey's access to the corridors of power. He also maps the true complexity of Southey's ideas for improving the nation, which mixed reactionary conservatism in the realm of public discourse with considerable radicalism when addressing issues such as land use and the role of communities.

7. Southey's skill as a Hispanist is often cited, but his engagements with Spanish literature and culture remain underexplored aspects of his career. Jonatan González's essay makes an important contribution to correcting this neglect through its examination of Southey's extensive engagements with Lope de Vega. These engagements include direct quotations in Joan of Arc and Roderick, the Last of the Goths, translations and reworkings in shorter verse forms, and a shifting series of critical accounts in editions of the Letters Written during a Short Residence in Spain and Portugal and the Quarterly Review. Southey saw the "Phoenix of Wits" as both a potential kindred spirit in terms of ambition, skill, and productivity, and a problematic representative of continental superstition and excess. González's account demonstrates that Southey remained conflicted about Lope throughout his career, but also shows that he significantly moderated his earlier positions as he read further and built up a more complex network of understanding and affinity.

8. Tom Duggett's essay also explores Southey's Hispanist connections. Drawing on work conducted while preparing the new edition of Southey's Sir Thomas More: or, Colloquies on the Progress and Prospects of Society, Duggett divines the many potential meanings of Montesinos, the more ambiguous and complex of the two dialogists who assess the condition of England in Southey's meditations. Marrying discussions of Southey's literary utopianism with detailed considerations of his Iberian expertise, Duggett shows how Southey sought to position his colloquies carefully within national and world-spanning historical, literary, and philosophical traditions. The essay demonstrates that rather than being a deliberately ambiguous 


\section{Romanticism on the Net \#68-69 (Spring-Fall 2017). Special issue on Robert Southey. Guest-edited by Tim Fulford (De Montfort University) and Matthew Sangster (University of Glasgow)}

sign, Montesinos serves as a hieroglyph for a whole complex of Southey's projecting fascinations.

9. Joseph DeFalco Lamperez also plumbs Southey's complex use of image and metaphor in his examination of the ways in which Southey employed Hinduism to understand the developing manufacturing system. Taking the Colloquies and The Curse of Kehama as his principal foci, Lamperez argues convincingly that the metaphorical resources that Southey smelted out of his partial understanding of Indian religions provided him with means for apprehending and modelling the magnitude of the Industrial Revolution, with Hindu customs and rituals serving in his works as a correlative for the intertwined complexities of imperial and technological networks.

10. Adam Colman's essay on Southeyan techniques and the science of air approaches The Curse of Kehama from a different angle. Colman considers the consequences of Southey's 1790s interactions at Thomas Beddoes' Pneumatic Institution in Bristol, arguing that his experiences had a lingering influence on the ways that Southey figured hope, desire, and craving in his poetry. The article subtly demonstrates that Southey's ambivalent attitudes to naturalphilosophical ecstasy shaped his poetry at the level of form as well as that of content, showing his formidable talent for forging verse that aimed at evoking material experience through its volatility, anticipations, and disjunctions.

11. The final three essays in this special issue all deal with Southey's engagements with particular British localities, showing the ways in which his works activated the different intellectual and affective potentialities of the areas through which he passed and in which he resided. Matthew C. Jones's account of the poems on Welsh subjects that Southey published in the Morning Post in 1798 examines how Southey uses Welsh cultural history tied to specific locations in order to promote a radical vision that leagues British citizens together against the exercise of arbitrary power. Jones examines both the successes of Southey's evocations and the tensions that they manifest, considering the distinctions between nations that the poems implicitly uphold, and the ways in which Southey moderated his views through deflection into pasts and peripheries in order to render his ideals in forms that could be published without undue risk. 


\section{Romanticism on the Net \#68-69 (Spring-Fall 2017). Special issue on Robert Southey. Guest-edited by Tim Fulford (De Montfort University) and Matthew Sangster (University of Glasgow)}

12. In an essay that fluently contradicts H. J. Jackson's assertion that Southey did not write about the Lakes (58), Joanna E. Taylor demonstrates the extent to which he invested affectively, culturally, and aesthetically in Keswick and its surroundings. In writing his relationships with family and friends into the landscape, Southey displayed an intense fidelity to particular locations while also working to connect his present locality with longer legacies of habitation and with wider national and global communities. In exploring the ways in which Southey's works constructed a bioregion around his long-term residence, Taylor seeks to nuance ecocritical accounts that have unduly privileged the relationship between the individual and the natural world, arguing that historical and affective community-building across a range of scales plays a crucial role in imbuing the connections between people and places with meaning.

13. Finally, Matthew Sangster's essay on London follows Southey into an environment that he heartily despised, exploring the continuities and discontinuities in his writings on the city from his schooldays in the $1780 \mathrm{~s}$ and $1790 \mathrm{~s}$ to his time as a greying eminence in the $1830 \mathrm{~s}$. It contrasts Southey's rare engagements with the metropolis in his poetry with the more extensive accounts in his private correspondence and prose writings, reading his depictions of the city as a place of filth, inequality, and tedious sublimity alongside negative appraisals by Wordsworth and Coleridge. The article demonstrates that Southey's attitudes to the city reflect not just his own experiences as a visitor but also the cultural and disciplinary systems that positioned London as a nexus of collective activity. Men of letters were increasingly compelled to define themselves against this collectivity because, in a competitive publishing market, literary value was increasingly related to the ability to express profound subjectivity.

14. Southey's own reason for believing that his memoirs would be of ongoing interest was that they would "contain so much of the literary history of the times as to have a permanent value on that account" (CLRS 2078). In this formation, Southey implicitly positions himself at the centre of his age, intrinsically entangled with its governing figures and paradigms. However, his permanent value might best be seen as arising from the more complex fact that he was both right and wrong about his centrality, in several senses. In his own time, Southey was influential and much discussed, but he was by no means universally accepted as a dominant cultural figure either commercially or critically, in part because of his complex politics and in part because of the unconventionality of many of his works. When Romanticism became the standard prism for 


\section{Romanticism on the Net \#68-69 (Spring-Fall 2017). Special issue on Robert Southey. Guest-edited by Tim Fulford (De Montfort University) and Matthew Sangster (University of Glasgow)}

viewing his period, he was condemned principally to the position of purse-lipped foil for writers deemed more radical and imaginative than he was: an antique curiosity, rather than the author of a living body of work. However, moving beyond twentieth-century totalisations has allowed a more complex and conflicted Southey to emerge. This Southey is a valuable figure for tracing the literary culture of the late eighteenth and early nineteenth centuries not only because his works contain once-dominant paradigms, but also because of their idiosyncratic interests, their particular curiosities, and the moments that either always were or have subsequently become startlingly original and strange. At his best, Southey could be profound, funny, caring, insightful, compendious, and inventive in ways that remain tremendously compelling. While he can serve as a rich means for connecting things together, he is also precious for the brilliant, quotidian, quixotic, and inspiring ways that he sought to build his links. 


\section{Romanticism on the Net \#68-69 (Spring-Fall 2017). Special issue on Robert Southey. Guest-edited by Tim Fulford (De Montfort University) and Matthew Sangster (University of Glasgow)}

\section{Works Cited}

Andrews, Stuart. Robert Southey: History, Politics, Religion. New York: Palgrave, 2011.

Bolton, Carol. Writing the Empire: Robert Southey and Romantic Colonialism. London: Pickering \& Chatto, 2007.

Butler, Marilyn. "Repossessing the Past: The Case for an Open Literary History." Rethinking Historicism: Critical Readings in Romantic History, edited by Marjorie Levinson et al., Oxford: Blackwell, 1989, pp. 64-84.

Craig, David M. Robert Southey and Romantic Apostasy: Political Argument in Britain, 1780-1840. Woodbridge: The Boydell Press, 2007.

Cross, Ashley. Mary Robinson and the Genesis of Romanticism: Literary Dialogues and Debts, 17841821. London and New York: Routledge, 2016.

Cutmore, Jonathan, editor. The Quarterly Review Archive. University of Maryland: Romantic Circles, February 2005, https://www.rc.umd.edu/reference/qr/index.html.

Fulford, Tim. The Late Poetry of the Lake Poets: Romanticism Revised. Cambridge: Cambridge University Press, 2013.

---. Romantic Poetry and Literary Coteries: The Dialect of the Tribe. Basingstoke: Palgrave Macmillan, 2015.

Fulford, Tim, and Peter J. Kitson, editors. Romanticism and Colonialism: Writing and Empire, 17801830. Cambridge: Cambridge University Press, 1998.

Gamer, Michael. Romanticism, Self-Canonization, and the Business of Poetry. Cambridge: Cambridge University Press, 2017.

Garcia, Humberto. Islam and the English Enlightenment, 1670-1840. Baltimore, MD: Johns Hopkins University Press, 2011.

Hill, Jen. White Horizon: The Arctic in the Nineteenth-Century British Imagination. Albany, NY: State University of New York Press, 2008.

Jackson, H. J. Those Who Write for Immortality: Romantic Reputations and the Dream of Lasting Fame. New Haven and London: Yale University Press, 2015.

Leask, Nigel. British Romantic Writers and the East: Anxieties of Empire. Cambridge: Cambridge University Press, 1992.

McGann, Jerome J. The Romantic Ideology: A Critical Investigation. Chicago: University of Chicago Press, 1983. 


\section{Romanticism on the Net \#68-69 (Spring-Fall 2017). Special issue on Robert Southey. Guest-edited by Tim Fulford (De Montfort University) and Matthew Sangster (University of Glasgow)}

Mullan, John. "Marilyn Butler obituary." The Guardian, 13 March 2014, https://www.theguardian.com/books/2014/mar/13/marilyn-butler.

Pratt, Lynda. "Preface". Romanticism, vol. 17, issue 1, 2011, p. v.

---, ed. Robert Southey. Romanticism on the Net, no. 32-33, 2003-2004, https://www.erudit.org/en/journals/ron/2003-n32-33-ron769/.

---, ed. Robert Southey and the Contexts of English Romanticism. Aldershot and Burlington, VT: Ashgate, 2006.

Rudd, Andrew. Sympathy and India in British Literature, 1770-1830. Basingstoke: Palgrave Macmillan, 2011.

Siskin, Clifford. The Historicity of Romantic Discourse. New York and Oxford: Oxford University Press, 1988.

Southey, Robert. The Collected Letters of Robert Southey: A Romantic Circles Electronic Edition.

General editors Lynda Pratt, Tim Fulford, and Ian Packer, University of Maryland: Romantic Circles Electronic Editions, 2009-, http://www.rc.umd.edu/editions/southey_letters. (CLRS).

---. Later Poetical Works, 1811-1838. Edited by Lynda Pratt, Tim Fulford, Carol Bolton, Ian Packer,

Diego Saglia, Daniel E. White, and Rachel Crawford, 4 vols, London: Pickering \& Chatto, 2012. $(L P W)$.

---. Letters from England by Don Manuel Alvarez Espriella. Edited by Carol Bolton, London and New York: Routledge, 2016. (LFE).

---. Poetical Works 1793-1810. Edited by Lynda Pratt, Tim Fulford, and Daniel Sanjiv Roberts, 5 vols, London: Pickering \& Chatto, 2004. $(E P W)$.

---. Sir Thomas More: or, Colloquies on the Progress and Prospects of Society. Edited by Tom Duggett, 2 vols, London and New York: Routledge, 2017. (STM).

Speck, W. A. Robert Southey: Entire Man of Letters. New Haven: Yale University Press, 2006.

Storey, Mark. Robert Southey: A Life. Oxford: Oxford University Press, 1997.

Wallbank, Adrian J. Dialogue, Didacticism and the Genres of Dispute: Literary Dialogues in an Age of Revolution. London: Pickering \& Chatto, 2012.

Warren, Andrew. The Orient and the Young Romantics. Cambridge: Cambridge University Press, 2014.

Watson, Alex. Romantic Marginality: Nationality and Empire on the Borders of the Page. London: Pickering \& Chatto, 2012. 